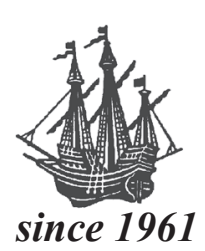

Baltica

BALTICA Volume 34 Number 2 December 2021: 203-215

https://doi.org/10.5200/baltica.2021.2.6

\title{
Environmental issues in the coastal regions of the south-eastern Baltic Sea: A sensitive natural environment in the face of increasing anthropic pressures
}

\author{
Sébastien Gadal*, Thomas Gloaguen
}

Gadal, S., Gloaguen, T. 2021. Environmental issues in the coastal regions of the south-eastern Baltic Sea: A sensitive natural environment in the face of increasing anthropic pressures. Baltica, 34 (2), 203-215. Vilnius. ISSN 1648-858X. Manuscript submitted 1 April 2021 / Accepted 30 November 2021 / Available online 20 December 2021

(C) Baltica 2021

\begin{abstract}
In recent years, Latvian, Lithuanian, and the Oblast of Kaliningrad coastal zones have been experiencing a particularly intense and rapid anthropisation of the coastline due to political, social, and economic changes at the end of the Soviet period. These pressures are exerting on a highly sensitive environment, which has remained relatively untouched by any major development due to the militarisation of the coasts. The human stakes increased considerably in the coastal zone of the south-eastern Baltic with tourism, industrial development, and urban expansion. The environmental impacts and issues of the post-soviet anthropisation are analysed in this article through a bibliographic compilation related to the evolution of the coastal management policies reconciling environmental protection and economic development.
\end{abstract}

Keywords: environmental issues; coastal zone; coastal management; anthropic pressure; South-Eastern Baltic

Sébastien Gadal*(sebastien.gadal@univ-amu.fr)Aix-Marseille Université, Université Côte-d'Azur, Avignon Université, CNRS, ESPACE, UMR 7300, 13545 Aix-en-Provence Cedex 04, France; North-Eastern Federal University, Republic of Sakha Yakutia, 670000 Yakutsk, Russian Federation, Thomas Gloaguen(thomas.gloaguen@ktu.edu) Kaunas University of Technology, Faculty of Civil Engineering and Architecture, Cultural and Spatial Environment Research Group, LT-51367 Kaunas, Lithuania; Aix-Marseille Université, Université Côte-d'Azur, Avignon Université, CNRS, ESPACE, UMR 7300, 13545 Aix-en-Provence Cedex 04, France

*Corresponding author

\section{INTRODUCTION}

In recent decades, most of the world's coastal areas have experienced coastalisation marked by an increasing concentration of populations and economic activities (tourism, shipbuilding, and port industries, for example) close to the shore (Pranzini, Williams 2013; Afanasyeva 2014). This process has direct and indirect consequences on specific ecosystems and landscapes manifesting through the creation or reinforcement of existing environmental problems such as coastal erosion, oil spills, eutrophication, etc. (Olenina, Olenin 2002; Afanasyeva 2014). Since the 1960s, global environmental awareness has led the public authorities to introduce management policies that bring together various programmes, projects, legal, organizational, and financial measures aimed at reconciling environmental protection and economic development (Mochalov 1999; Povilanskas, Urbis 2004; Afanasyeva 2014).

The unique development of the south-eastern Baltic Sea (Fig. 1) is strongly linked to the changes in political, social, and economic regimes that took place with the collapse of the Soviet Union in the early 1990s (Gadal 2010). These geopolitics changes have had a direct impact on the process of coastalisation and coastal land uses since the $1990 \mathrm{~s}$, with the demilitarisation of coastal territories, the privatisation of property, and the development of economic activities centred on tourism and industry. In the face of these changes, the policies and strategies developed since the Soviet era - including in new governance at the European level with the accession of Lithuania and Latvia in 2004 - in implementing sustainable coastal planning between the southeast Baltic Sea countries are here analysed. 


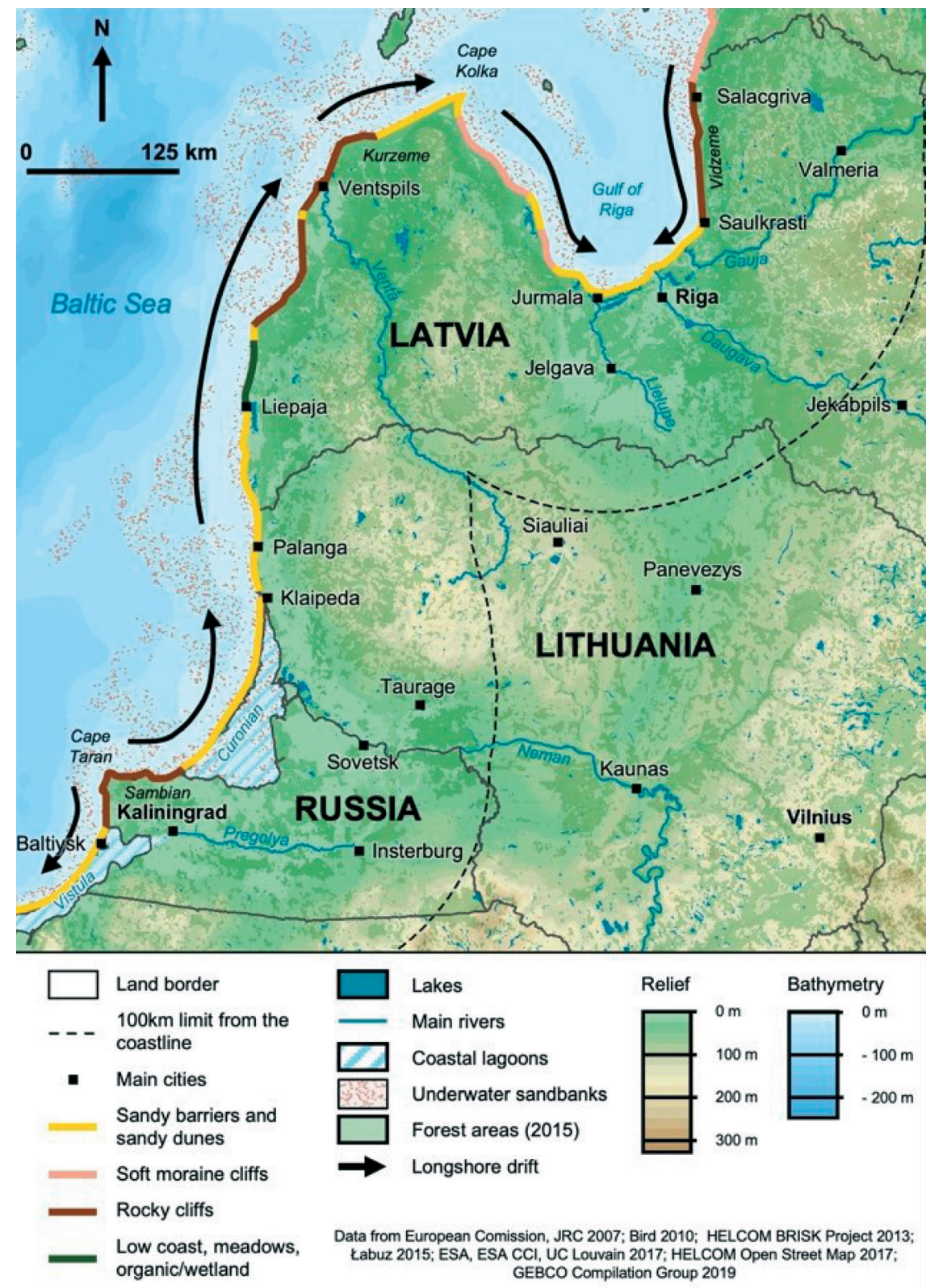

Fig. 1 Natural context and coastal dynamics of the study coastline

\section{METHODOLOGY}

This research is mainly based on the compilation of scientific articles on the environmental problems observed in the south-eastern Baltic region. Among the environmental problems identified by Eaglet (1999) and Olenina, Olenin (2002) on a regional scale, we decided to focus on two main ones, namely erosion and degradation of coastal ecosystems (Bagdanavičiūtè et al. 2012; Łabuz 2015; Karmanov et al. 2018) and pollution and eutrophication (Andersen et al. 2017; Lavrova 2019).

This analysis was accompanied by a synthesis of the various evaluations carried out by international organisations such as the Baltic Marine Environment Protection Commission (HELCOM (a) 2018; HELCOM (b) 2018), the OECD (OECD 2019) or the
European Union (Kraus, Meyer 1998). On this basis, we identified different legislative, financial and technical measures for the protection and management of coastal regions (Povilanskas, Urbis 2004; Moritz 2008; Bass 2015), as well as their main advantages and limitations.

We also focused our research on the anthropisation of coastal regions, in particular through the prism of studies on changes in land use (Gadal 2010; Veteikis et al. 2011) and on the historical and geopolitical context of the end of the Soviet period in which these dynamics took place (Gadal 2011; Nitavska, Zigmunde 2013).

Geographic data were used to support the literature review (Table 1). The data was downloaded from database platforms (e.g. Resource Watch, HELCOM Map and Data Service), processed in GIS and extract- 
Table 1 Sources of geographical data used

\begin{tabular}{|l|c|}
\hline \multicolumn{1}{|c|}{ Nature of the data } & Source of the data \\
\hline $\begin{array}{l}\text { Underwater sandbanks } \\
\text { Coastal lagoons }\end{array}$ & Helcom brisk Project 2013 \\
\hline Bathymetry & GEBCO 2019 \\
\hline $\begin{array}{l}\text { Nitrogen concentration } \\
\text { Phosphorus concentration } \\
\begin{array}{l}\text { Plastic pollution of beaches } \\
\text { Dredge disposal sites }\end{array}\end{array}$ & $\begin{array}{r}\text { HELCOM (a) } 2018 \\
\text { HELCOM (b) } 2018\end{array}$ \\
\hline Lakes and rivers & Vogt et al. 2007 \\
\hline Land cover & ESA 2017 \\
\hline Relief & Danielson, Dean 2010 \\
\hline Population & $\begin{array}{r}\text { Ciesin 2012 } \\
\text { Sciavina } \text { et al. } 2019\end{array}$ \\
\hline
\end{tabular}

ed for the regions of interest for mapping or geostatistical purposes.

Field surveys were conducted in September and October 2020 at the sites in Klaipeda, Palanga, Curonian Spit National Park (Lithuania), as well as Riga, Jurmala, Ventspils, Kolka, and Saulkrasti (Latvia). The survey data acquired includes geo-located photographs and field observations on the markers of coastalisation of the south-eastern Baltic region and environmental protection measures.

\section{CONTEXT}

Political, social, and economic changes leading to rapid anthropisation of the coastal zone

\section{The Soviet period: Military control and economic specialisation of coastal zones}

Until the early 1990s, during the time of the Soviet Union, a dual process of (1) militarisation and (2) economic planning influenced the development of the coastal zones of the south-eastern Baltic Sea countries (Veteikis et al. 2011; Pranzini, Williams 2013; Spiriajevas 2014).

The coastal territories formed the external border of the Soviet Union (USSR) and acquired, in fact, the status of "semi-enclosed zones", to which access was severely restricted and which limited the existence of densely populated areas close to the shore (Pranzini, Williams 2013; Spiriajevas 2014). Except for Liepāja, Ventspils and Riga, the Latvian coasts remained sparsely populated: the population density of the counties of Limbaži or Talsi districts was only 15 and 18 inhabitants $/ \mathrm{km}^{2}$, respectively, in 1990. By comparison, some regions in southern Sweden (Blekinge county, 46 inhabitants $\left./ \mathrm{km}^{2}\right)$, Denmark (Sjælland region, 106 inhabitants $/ \mathrm{km}^{2}$ ) or Germany (Mecklenburg-Vorpommern state, 74 inhabitants $/ \mathrm{km}^{2}$ ) were much more populated at the same time (Sciavina et al. 2019). The militarisation of the coast also led to the loss of traditional landscapes, such as fishing vil- lages, and individual cultural and historical objects (Nitavska, Zigmunde 2013).

At the same time, the Soviet system pursued a policy of economic planning which implied investment choices: due to the interface role of the coasts, this specialisation concerned specific sectors related to fishing, tourism, naval construction (mostly military), and port industries, as observed in Kaliningrad Oblast (Fedorov et al. 2017). Choices were also made in terms of production, particularly in the agricultural sector. The effects of the land collectivisation policy initiated in the 1940s were significant: in Latvia, the rural landscape was considerably changed, the population moved massively to the cities, forcing the authorities to adopt "standardised architectural solutions", notably Soviet housing estates built quickly to accommodate large numbers of people (Nitavska, Zigmunde 2013).

The changes produced during the time of the Soviet Union are still having an impact on the development of the coastal areas of these countries, now under the influence of a liberal system that is gradually increasing the process of coastalisation.

\section{The opening towards a liberal system: a gradual coastalisation of the south-eastern Baltic Sea coastal regions}

The economic liberalisation following the collapse of the USSR at the beginning of the 1990s has led to an increasing concentration of economic activities in coastal areas: the coastal zone now accounts for 5.3\% of Latvia's gross domestic product (GDP) and up to $12 \%$ of Lithuania's GDP (Brunina et al. 2011; Veteikis et al. 2011; Fedorov et al. 2017).

The economic specialisation initiated under the Soviet system continued and intensified: "traditional" activities such as artisanal fishing or agriculture declined toward other activities which took advantage of greater economic openness to develop strongly (Eaglet 1999; Spiriajevas 2014; Fedorov et al. 2017). These two main activities are:

- Industrial, manufacturing, and harbour activities, whose main centres are located at Klaipeda, Riga, Ventspils, and Liepāja (Bitinas et al. 2005; Gulbinskas et al. 2009; Veteikis et al. 2011; Pranzini, Williams 2013; Spiriajevas 2014); and

- Tourist and recreational activities (Fig. 2) developing considerably throughout the coastal region with the enhancement of the architectural and historical heritage (military sites, fishing villages) and the natural heritage through the creation of protected areas (Natura 2000 sites), seaside resorts, and thermal baths (Palanga, Liepāja) (Eaglet 1999; Bitinas et al. 2005; Armaitienè et al.2007; Žilinskas 2008; 

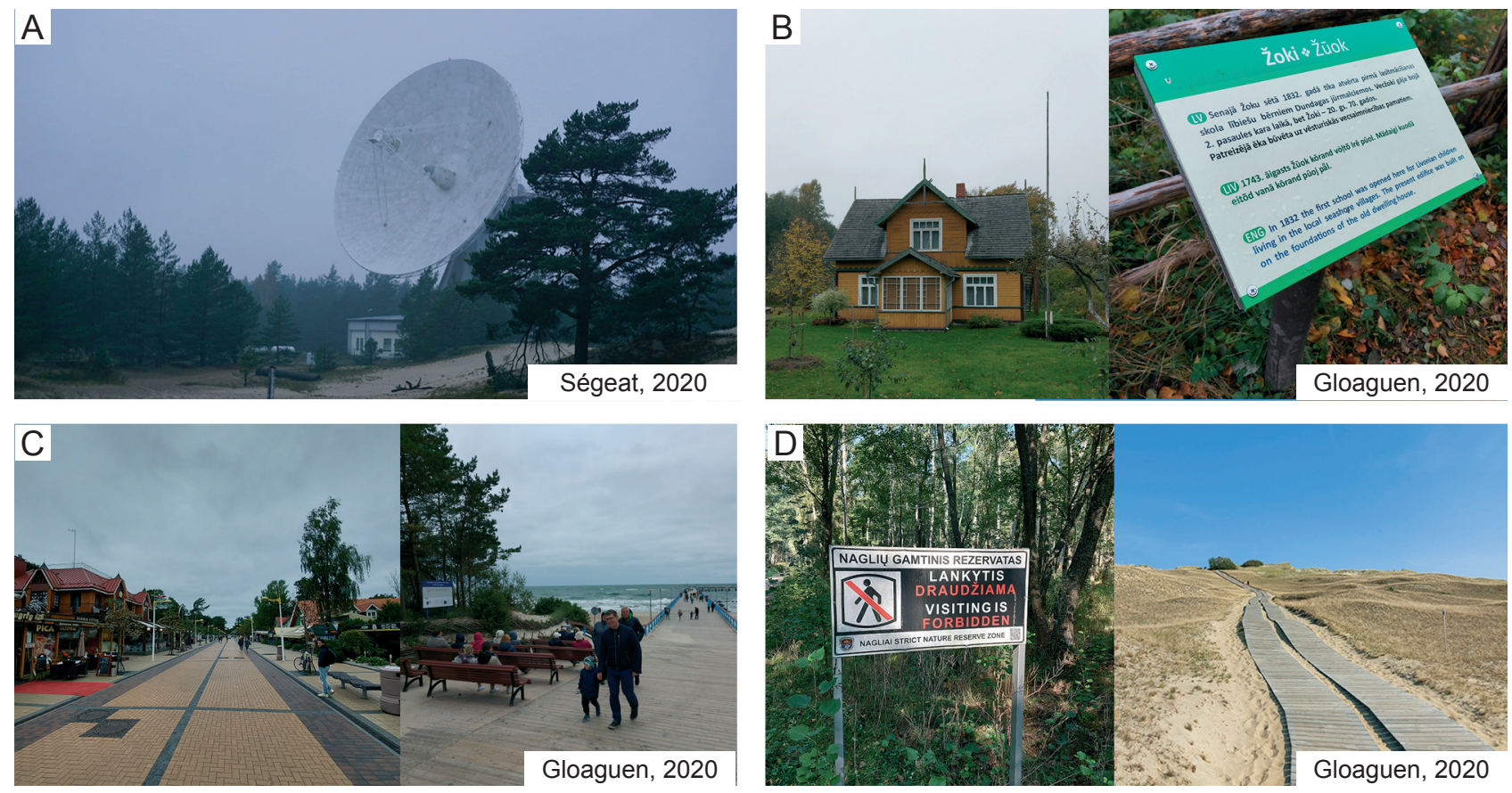

Fig. 2 Tourist and recreational activities in development on the Baltic coast. These activities are characterized by their great diversity:

- $[\mathrm{A}]$ the conversion of Soviet military installations such as the radio astronomy centre in Ventspils.

- $[\mathrm{B}]$ the conversion of traditional fishing villages (near Ventspils) where old houses and farms built in the early 20th century are signposted with information panels for tourists.

- $[\mathrm{C}]$ seaside tourism such as in Palanga with an important tourist offer of bicycles, restaurants, hotels, souvenir shops, etc.

- [D] nature tourism in the heart of protected parks, such as the Curonian Spit National Park in Lithuania, the use of which is strictly controlled

Gulbinskas et al. 2009; Brunina et al. 2011; Nitavska, Zigmunde 2013; Pranzini, Williams 2013; Afanasyeva 2014; Spiriajevas 2014; Mishurinsky, Bredikhin 2015; Fedorov et al. 2017).

The transition to a liberal economic and political system is also responsible for the increasing concentration of populations in these same areas, although "coastline has always been a desired living place" (Brunina et al. 2011). There are notable differences between the three countries in the study.

The Latvian coast is "the most densely populated coastal area in the Baltic's countries": in 2010, 77\% of the population lived within a $100 \mathrm{~km}$ coastal strip compared to $73 \%$ in Estonia and only $22 \%$ in Lithuania (Brunina et al. 2011; CIESIN 2012; Pranzini, Williams 2013). The largest increases in urbanised areas over the last 20 years have been in most coastal areas (Fig. 3) (ESA 2017). However, this coastal area is still relatively unoccupied, since a third of the coastline has sections with low or very low building density (Pranzini, Williams 2013). The forested areas covering $2 / 3$ of the coastal region are tending to decrease due to the "excessive exploitation of natural resources" attributed to agriculture and forestry (Fig. 3) (Kraus, Meyer 1998; ESA 2017).
In Lithuania, urbanisation has mainly taken place on the mainland coast, around Klaipeda and its surroundings, as well as in Palanga (Vaitkus, Vaitkuvienè 2005; Veteikis et al. 2011). This concentration can be partly explained by a short length of the coast, only about $100 \mathrm{~km}$ (Vaitkus, Vaitkuviene 2005). On the other hand, over the last 20 years, the largest increase in urbanised areas has occurred mainly outside a coastal strip of $100 \mathrm{~km}$. Forest cover has been maintained, while agricultural areas have been declining (Fig. 3) (ESA 2017).

In Kaliningrad Oblast, there is a high concentration of population in the coastal zone: $84.4 \%$ of the population of the oblast occupied a coastal strip of $50 \mathrm{~km}$ in 2015 (Fedorov et al. 2017). The most sensitive variations are found near the shore. As in Lithuania, forest areas have increased in contrast to agricultural areas (Fig. 3) (ESA 2017).

Overall, in these three countries, "economic growth and increase of population are reflected in the landscape by increase of construction and decrease of natural territories", notably in Latvia - with an $8 \%$ decrease in the forest area in the coastal strip between 1995 and 2015 (Fig. 3). The semi-natural and agricultural areas are also concerned with a decrease of 3 and $9 \%$ in agricultural areas in Lithuania and Russia, 

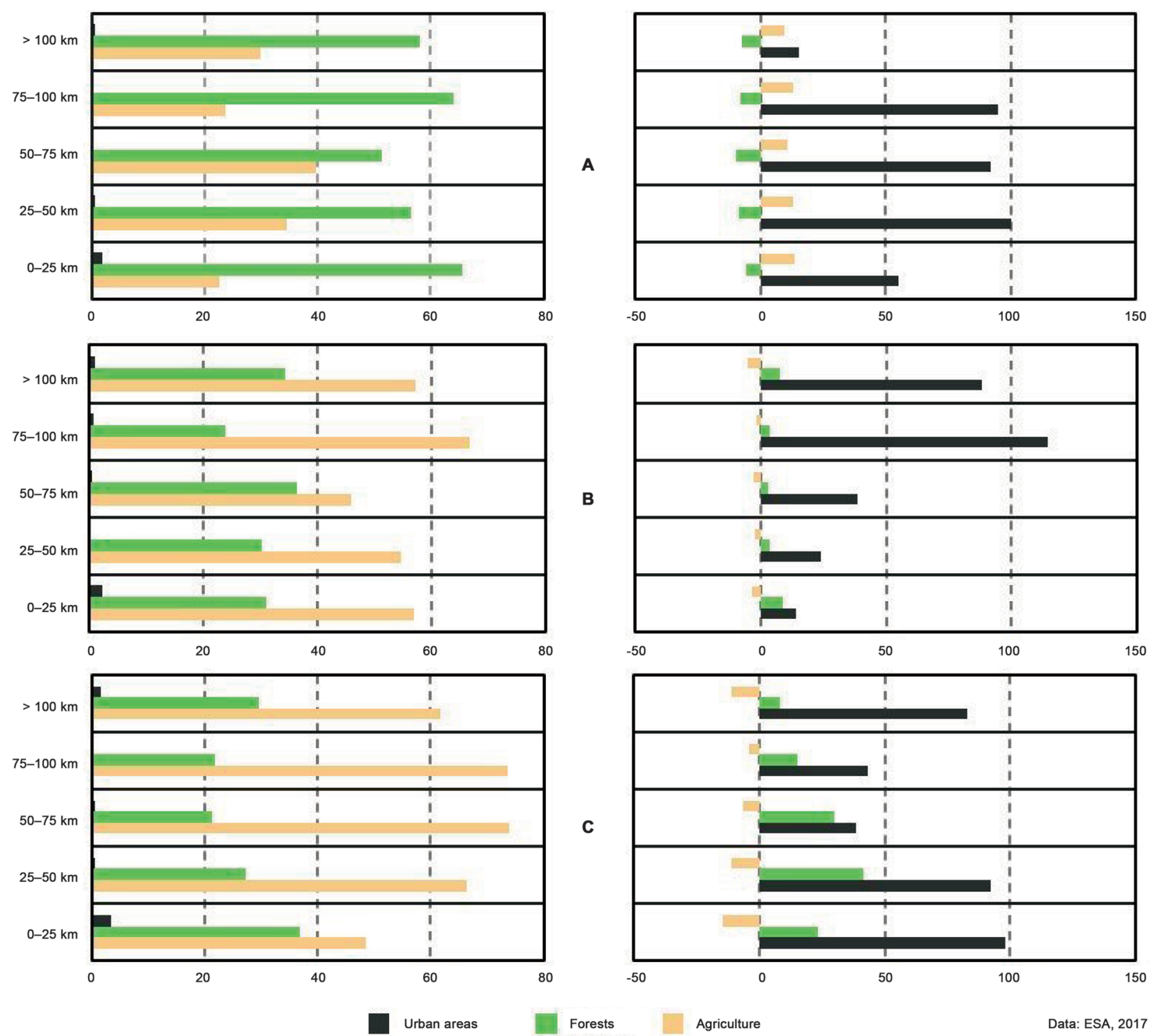

Fig. 3 An ever-increasing urbanisation of the shores. Shares of land use classes in each zoning from the coast in 2015 (left) and change between 1995 and 2015 (right) in Latvia [A], Lithuania [B] and Russia [C]

respectively, even though there was stabilisation or increase in forest areas due to effective management of these resources (Fig. 3) (Gadal 2011; Nitavska, Zigmunde 2013). Today, it is in most coastal areas that the concentration of urbanised areas is the highest (Fig. 4) (ESA 2017). This trend was accentuated after 1991, with independence and liberalization of economic systems and land management: "the tendencies of the aspects of chaotic territorial development $[\ldots]$ make permanent penetration for intensification of urbanised process" (Spiriajevas 2014). The abandonment of agricultural land due to the loss of economic value of the agricultural sector has led to the development of second homes, which is at the origin of the increase in the surface area of urban areas observed in the coastal strip of the three countries (Spiriajevas 2014). The inexperience of new inhabitants linked to the re-establishment of property rights has led to numerous abuses: restricted access to the coast by national legislation, unsuitability of reconstructions with specificities of the landscape and natural coastal processes, and abusive use of natural resources (Spiriajevas 2014).

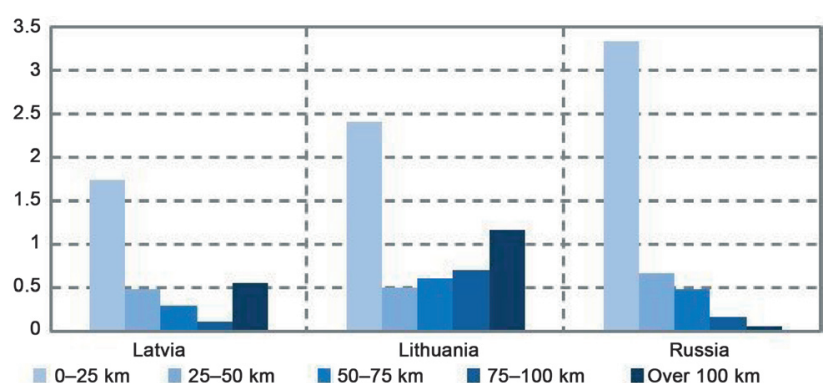

Fig. 4 Share of urban areas in each zoning from the coastline. Data: ESA 2017 


\section{A unique and sensitive environment resulting from multiple natural dynamics}

The $730 \mathrm{~km}$ long south-eastern Baltic Sea coastline is shared between Latvia (495 km), Lithuania $(90 \mathrm{~km})$, and Russia $(145 \mathrm{~km})$ with Kaliningrad Oblast (Pranzini, Williams 2013). Sand deposits characterise the major part of the coastline (Fig. 1) with (Gulbinskas et al. 2009; Bird 2010; Bagdanavičiūtè et al. 2012; Pranzini, Williams 2013):

- Wide sandy, sandy/gravel beaches (up to $100 \mathrm{~m}$ wide), especially on the coasts of the Vistula Spit, Curonian Spit, the Lithuanian mainland coast, the northern Kurzeme coast and the Gulf of Riga (Fig. 1) (Bird 2010; Łabuz 2015).

- Developed foredunes (with a width between $50 \mathrm{~m}$ and $150 \mathrm{~m}$ and a height generally between $3 \mathrm{~m}$ and $5 \mathrm{~m}$, or even up to $50 \mathrm{~m}$ ). Reforestation and revegetation operations have made it possible to fix dune migration, which was threatening some villages. Behind them, there is a sand accumulation plain with numerous wetlands, streams and pine forests (Povilanskas, Urbis 2004; Bitinas et al. 2005; Gulbinskas et al. 2009; Burnashov 2011; Pranzini, Williams 2013; Spiriajevas 2014)

- Sandbars (between $3 \mathrm{~m}$ and $6 \mathrm{~m}$ high), generally 3 to 4 in number, limiting the action of swells (Bitinas et al. 2005; Pranzini, Williams 2013).

The coastline is also dissected by cliffs dating from the glacial drift in several sections - Vidzeme coast, Sambia Peninsula, Kurzeme west coast (Fig. 1, 6a) (Bird 2010; Łabuz 2015). Their erosion provides sediments feeding the sandy coasts subject to important seasonal and cyclical changes (Bird 2010) produced by natural morphodynamic processes:

- The southwest, west, and northwest swells cause low energy waves (generally less than 5 m) (Bird 2010; Bagdanavičiūtè et al. 2012; Pranzini, Williams 2013). During autumn and winter storms, they can reach up to $13 \mathrm{~m}$ in height in association with a storm surge of 1.3 $\mathrm{m}$ to $1.8 \mathrm{~m}$ (Brunina et al. 2011; Pranzini, Williams 2013).

- Longshore drift transports (Fig. 1) the most recent sediments. Between Cape Taran and Cape Kolka, it is south-north, with a decreasing volume (from $500,000 \mathrm{~m}^{3} /$ year to $250,000 \mathrm{~m}^{3} /$ year) until the vicinity of Liepaja, then increasing again (up to 1 million $\mathrm{m}^{3} /$ year) at Cape Kolka. The drift takes a west-east direction between Cape Kolka and Riga, with a decreasing volume from the cape $\left(50,000 \mathrm{~m}^{3} /\right.$ year). Finally, the drift is in a north-south direction on the Vidzeme coast, with a decreasing volume from
Riga (from $25,000 \mathrm{~m}^{3} /$ year to $15,000 \mathrm{~m}^{3} /$ year). The drift takes the same direction between Cape Taran and the Polish border (Bitinas et al. 2005; Gulbinskas et al. 2009; Bird 2010; Pranzini, Williams 2013).

- The low tidal range $(5-10 \mathrm{~cm})$ is associated with the semi-diurnal tidal current (Pranzini, Williams 2013).

Some of the hotspots, whether shaped by natural dynamics or not, are now important coastal and marine habitats and species sites, such as the Curonian Spit which hosts several rare bird species (Peregrine and Red-Legged Falcons, Brown Kites and Pink Starlings). Their protection is essential to safeguard the biological diversity of coastal regions (Armaitiene et al. 2007; Bagdanavičiūtè et al. 2008; Moritz 2008).

\section{RESULTS}

\section{Environmental problems caused by coastal anthropisation}

The progressive anthropisation of the coast has created environmental problems or accentuated the existing ones. They are of different scale and intensity and cause damage to the coast and to the natural dynamics that control its evolution. Certain problems are the subject of particular attention from the public authorities (Bitinas et al. 2005; Brunina et al. 2011).

\section{Air, water, soil pollution and lagoon eutrophication}

Air, water and soil pollution linked to the current economic activities comes from stationary sources (maritime and motor transport; water, construction or industrial waste), as well as from other sources in Scandinavia and Poland (Eaglet 1999; Pranzini, Williams 2013). Some unidentified sources are also responsible for oil spills affecting wintering waterbirds, even though a decrease in the number and volume of such deposits has been observed (Olenina, Olenin 2002; HELCOM (a) 2018; Lavrova et al. 2019). Finally, part of this pollution is associated with military activities from the Second World War until the end of the USSR: dumps, ammunition depots (up to 80,000 units in the Baltic Sea), chemical substances, etc. (Eaglet 1999; Bitinas et al. 2005; Nitavska, Zigmunde 2013; HELCOM (b) 2018). The elimination and treatment of this pollution continue to be an important issue, especially as it exerts negative externalities on human activities, such as the deterioration of the recreational quality of coastal waters (Fig. 5) (Eaglet 1999; Vinogradova 2017). For example, except for some Finnish beaches, Lithuanian and Latvian beaches have the highest levels of plastic waste measures in the entire Baltic Sea (HELCOM (a) 2018). 


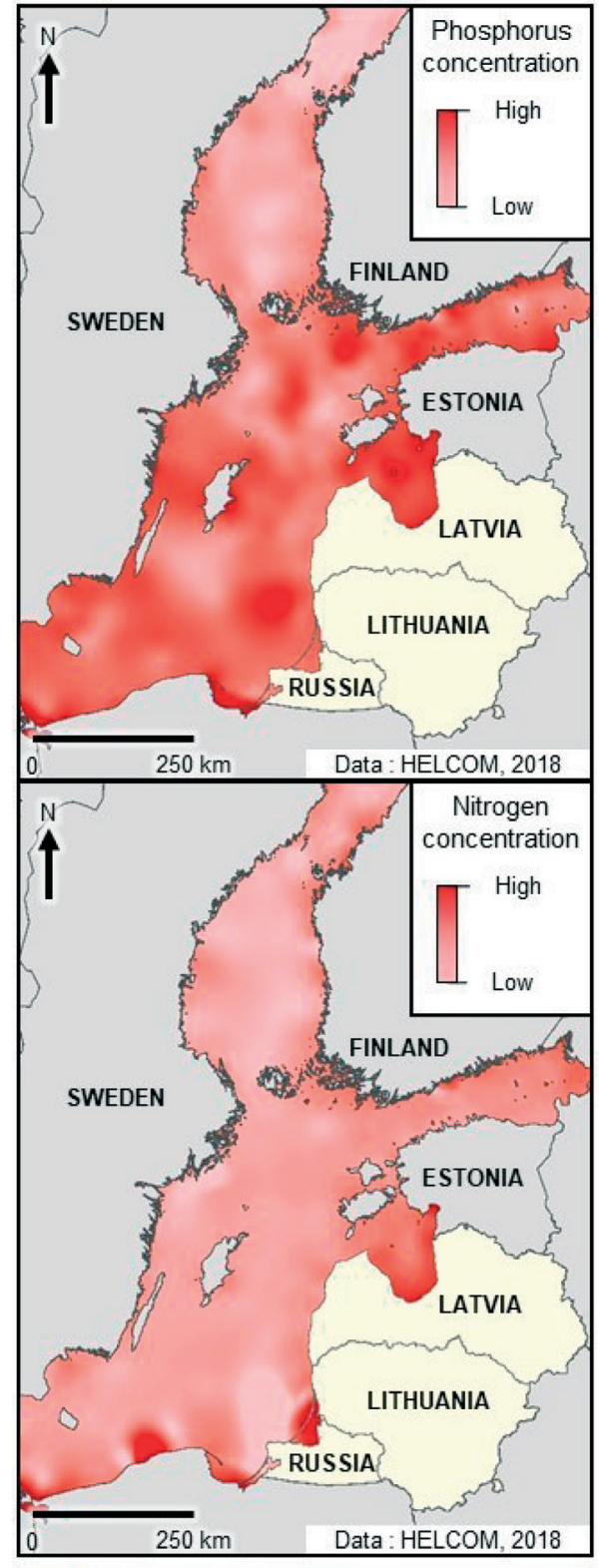

Informacija apie vandens kokybę paplüdimyje

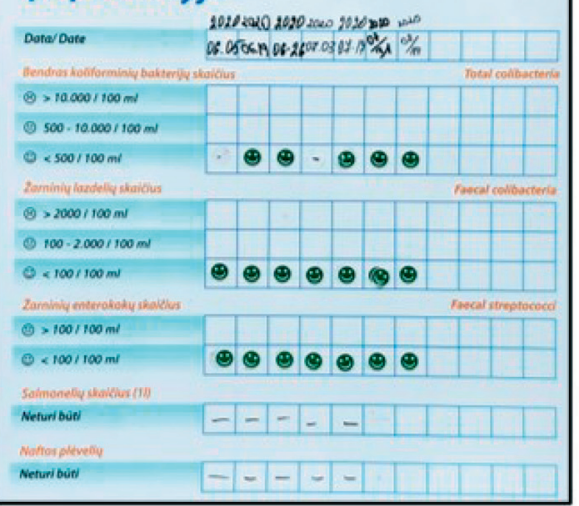

Fig. 5 Pollution and eutrophication at the heart of environmental concerns. [Up] The Gulf of Riga as well as the Lithuanian Baltic coast are among the most concentrated areas of phosphorus and nitrogen in the Baltic. [Below] Information board with water quality measurements detailed to the public (Klaipeda)
Pollution of rivers (Pregolya or Neman, for example) by human activities in the catchment areas, despite agricultural and industrial decline, causes an early eutrophication phenomena leading to an excess of fish mortality in the Curonian and Vistula lagoons (Eaglet 1999; Vinogradova 2017). Indeed, considerable disturbances in the level of nutrients (nitrate, phosphate, phosphorus, nitrogen) have been detected in the Baltic Sea, with a peak in the 1980s. These chemical fertilizers concentrations caused eutrophication processes that lead to biological imbalances in ecosystems and chronic anoxia. However, the implementation of efficient sewage treatment measures allows to limit and improve the "health" of the Baltic Sea (Olenina, Olenin 2002; Andersen et al. 2017).

\section{Degradation of coastal dunes and destruction of vegetation cover}

Tourism has negative effects on coastal ecosystems, especially when the tourist load becomes high during the summer period, while marine and coastal ecosystems (sand bars, dunes and vegetation for example) provide ecosystem services such as protecting human settlements from coastal erosion (Afanasyeva 2014). Tourists are responsible for the degradation of the vegetation cover, implying the reinforcement of the deflation of the dune crest. The trampling of dunes by bicycles or strollers further accentuates this process, as is the case in the southern Gulf of Riga, for example (Pranzini, Williams 2013; Žilinskas 2008). Beach access roads cut the dunes and dissect them, causing their rapid degradation. Works related to constructions behind the dunes cause further damage to the dune slopes (Žilinskas 2008). Problems concerning the protection of these dunes are observed in the Curonian Spit National Park (see Discussion) (Moritz 2008).

\section{Reinforcement of shoreline erosion}

Although the coastlines of the south-eastern Baltic Sea show a relatively stable overall trend, with a rate of change of $-1.13 \mathrm{~m} /$ year between 2007 and 2017 (EMODnet, TNO, Deltares 2019). Natural processes may explain the erosion of the Baltic coast (Fig. 6) (Gulbinskas et al. 2009; Pranzini, Williams 2013):

- Rising sea level. There was an acceleration of sea level rise in the Baltic Sea, estimated at $+0.4 \mathrm{~mm} /$ year between 1899 and 1875 compared to $+3.9 \mathrm{~mm} /$ year between 1975 and 2005 (Žilinskas 2008). These rapid and significant changes observed in recent years cannot be explained by isostatic movements of the Earth, which remained almost unchanged over the same periods. This rise in sea level 
causes "enhanced shore-erosion processes." (Jarmalavičius et al. 2001).

- With the increase in the frequency and duration of strong wind events, the return period for strong storms has recently reduced from $6-8$ years to $2-3$ years. The reinforcement of these winds is responsible for the weakening of foredunes (Žilinskas 2008).

- The increase in air and water temperature is responsible for the decrease in the number of
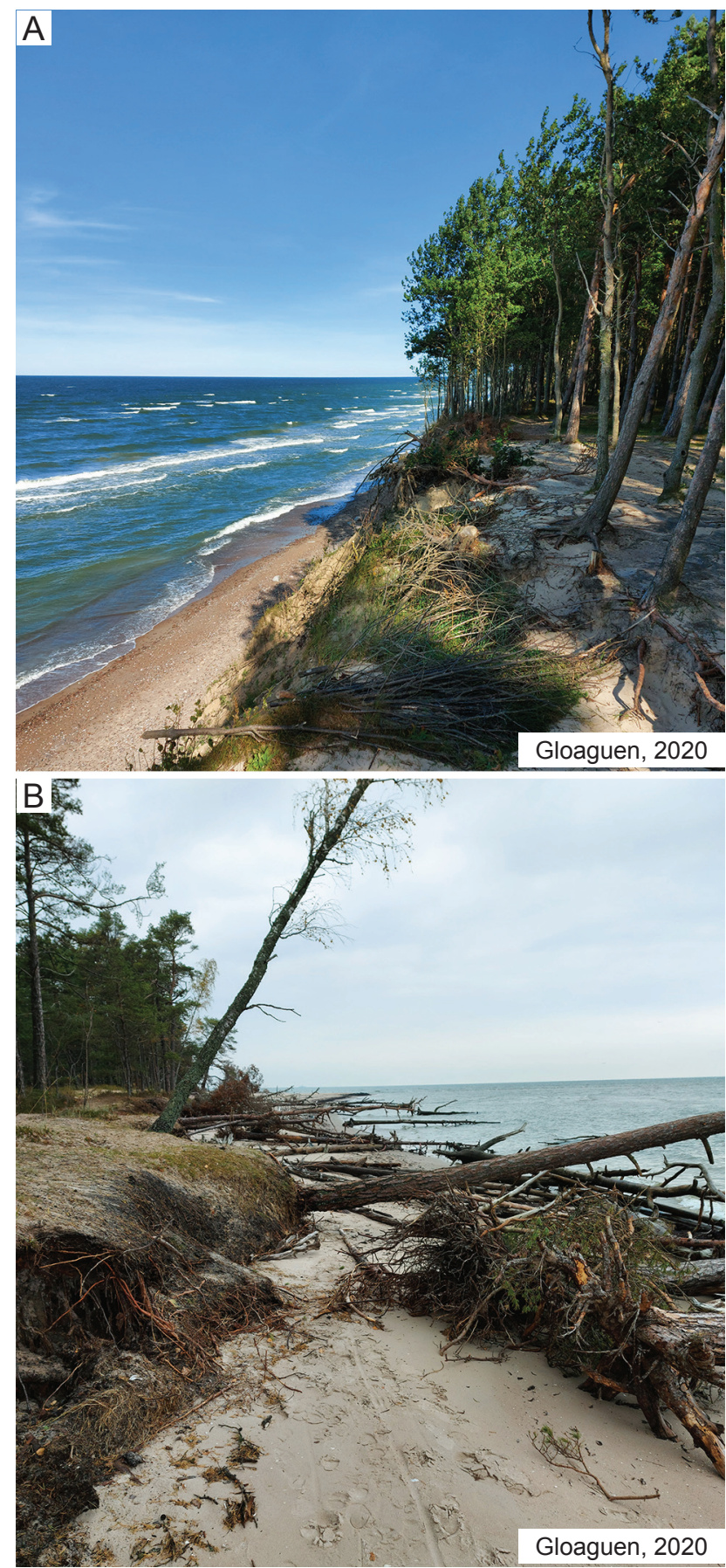

Fig. 6 Examples of eroding areas on the Baltic coast. [A] Erosion hotspots, cliffs and hills like on the Lithuanian mainland coast are strongly eroded during storm events. [B] The strongest swells caused several trees to fall on the beach at Kolka, for example days with snow, and ice cover serves as natural protection against erosion (Žilinskas 2008).

Other factors tend to show the evolution of the coast increasingly conditioned by humans, manifesting itself in terms of pressure and degradation.

The first factor is the disturbance of the inputs and sedimentary stocks necessary for the balance of the beaches. This reduction in the volume of sand is linked to the construction of hydroelectric dams on large coastal rivers (Daugava, Venta, Gauja) (Eaglet 1999; Pranzini, Williams 2013) and the depletion of coastal sedimentary reverses by human activities (degradation of dunes, dredging of sand and gravel required by the extension of ports) (Karmanov et al. 2018).

The second factor is the disturbance of natural forces controlling the evolution of the coastline by hydrotechnical constructions (dikes, breakwaters). These structures disturb the littoral drift and act as sand traps, causing chronic erosion on the coasts downstream of these developments (Bagdanavičiūtè et al. 2012; Jarmalavičius et al. 2012; Pranzini, Williams 2013; Karmanov et al. 2018). The most important peaks of variation are located near port infrastructures (Ventspils, Liepaja, Klaipeda) (Žilinskas 2008; Gulbinskas et al. 2009; Jarmalavičius et al. 2012; Pranzini, Williams, 2013).

\section{DISCUSSION}

\section{Progressive implementation of strategies for coastal protection and management}

Faced with increasing anthropogenic pressures on the coast, causing multiple environmental problems, the coastal protection and management strategies were put in place during the years of the Soviet Union and updated in recent years after the restoration of independence and integration in the European Union.

\section{Coastal protection measures: "soft" techniques and coastal defence}

The "soft" coastal protection techniques (Fig. 7) are notably applied in Lithuania, which has developed an approach with "limited intervention", from the National Coastal Zone Management Programme set up in 2003: it mainly aims at maintaining sandy beaches and preserving foreshores and forests by installing special fences to capture the sand, planting vegetation in dunes, etc. (Povilanskas, Urbis 2004; Gulbinskas et al. 2009; Pranzini, Williams 2013). This policy follows a progressive awareness of the problems caused by erosion even though coastal protection measures have been in place for a long time, dating back to the early $19^{\text {th }}$ century (Pranzini, Williams 2013). This strategy is most often applied within the numerous protected areas like the Curonian Spit National Park, 

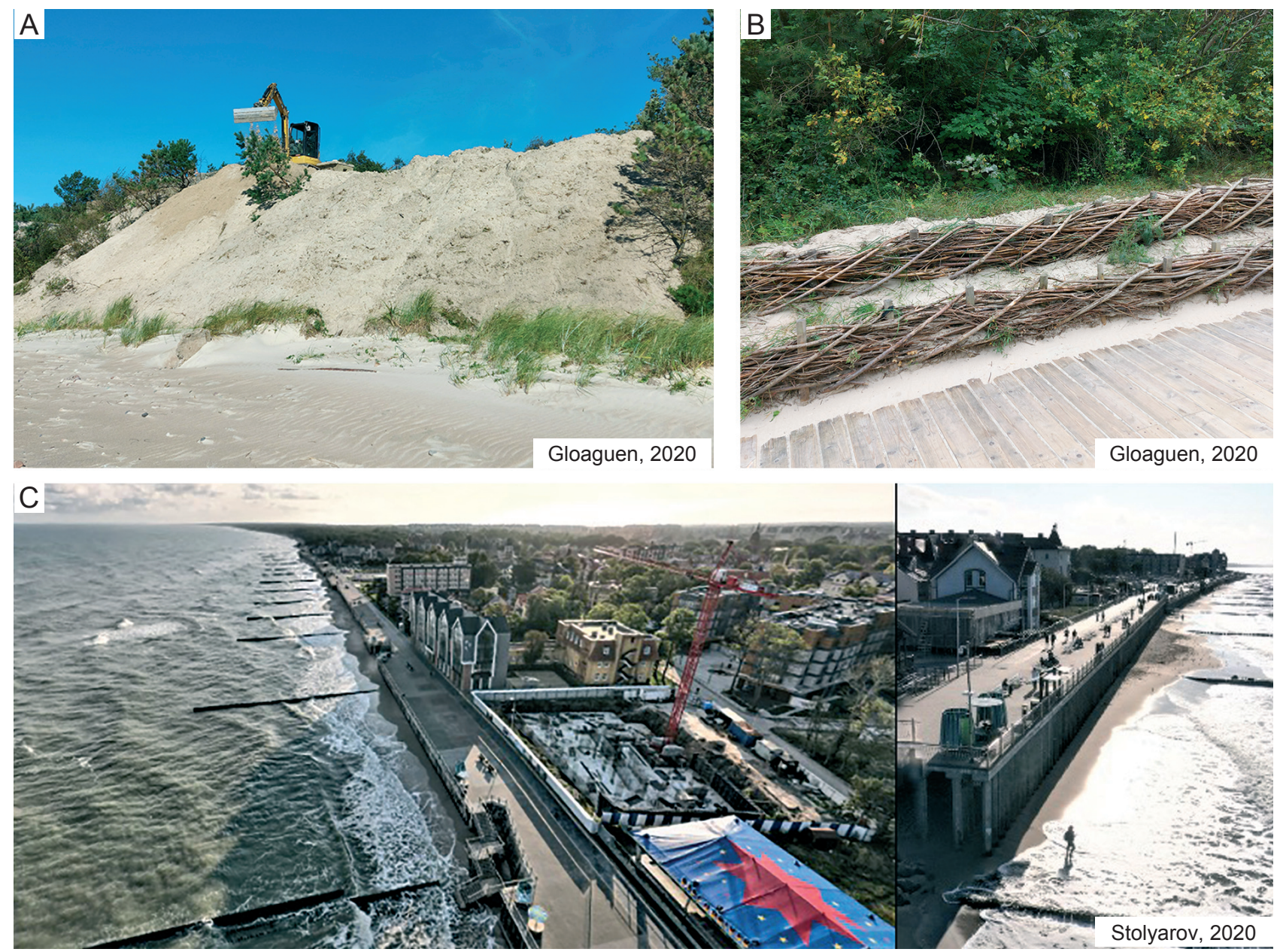

Fig. 7 Coastal protection measures. [A] Beach dune resurfacing and reinforcement works in the Lithuanian mainland coast. [B] Protection of the dune crest by natural materials with special fencing in Palanga. [C] Protective structures in the cities of the Sambian Peninsula, the beach is surmounted by several groynes and overhung by a seafront wall used as a promenade (with Google Street View)

which includes among their objectives the protection of natural coastal processes (Gulbinskas et al. 2009). Their network is quite dense in Lithuania and Latvia, and most of them are integrated with international programmes (Natura 2000, Interreg, Baltic Green Belt) which pursue natural and coastal heritage management objectives (Nitavska, Zigmunde 2013).

In Latvia, the authorities have only recently addressed the issue of erosion control, explaining the short length of the shoreline protected by coastal defences (only $4 \mathrm{~km}$ out of $485 \mathrm{~km}$ ). Most of the defences are created from natural materials (wood stones) by private owners although there are some hard defences (prisms, tetrapod) on the Kurzeme coast (Pranzini, Williams 2013).

In Kaliningrad Oblast, there is a long tradition of coastal protection developed by the Prussians. This protection is based on the system of fortified points and breakwater coastal walls, which is also used as a promenade wharf (Fig. 7). These structures were built and renewed several times at the end of the $19^{\text {th }}$ century, in the 1930s, and even recently, in the 1980s and 1990s. They are located mainly in the coastal settlements of the Sambian Peninsula concentrating several economic activities (Baltiysk) and in the $\mathrm{Cu}-$ ronian Spit National Park, which was protected only later. In the $20^{\text {th }}$ century, beach impoundment structures became widespread along the Russian coasts as they were considered the most effective in the fight again erosion. These structures support other complementary operations such as beach nourishment or dune support activities (Burnashov 2011; Pranzini, Williams 2013, Bass 2015).

\section{Coastal management measures: legislation and programmes}

Various laws and standards were created in the USSR in the early 1980s: they aimed to strike a balance between environmental protection and the development of economic activities by controlling " [...] location of recreation places for the national economy objects and arrangement of such territories [...]". The restricted access to the coastline created by military activities allowed natural areas to be preserved rela- 
tively well (Nitavska, Zigmunde 2013). Since independence, the legislative framework serving as a basis for environmental protection has evolved differently from one country to another.

In Lithuania, legislation is well developed: priority is given to the preservation of natural coastal processes and landscapes (Gulbinskas et al. 2009; Žilinskas 2008; Spiriajevas 2014). Several pieces of legislation determine the management and use of the coastal zones: the most important is the Law of the Coastal Zone of the Republic of Lithuania (2002), which provides "for safeguarding sustainable use of coastal zone for national and public use" and "safeguarding the implementation of protection measures for nature and cultural monuments" (Žilinskas 2008). The law imposes very strict provisions, such as the limitation of construction in a strip of 100 meters from the Baltic Sea coast and 50 meters from the Curonian Spit coast. Work on properties as well as their renovation or restoration is closely supervised, as the coastal strip is state property and any human activity must be regulated (Spiriajevas 2014). On the other hand, the country has set up an ambitious forest recovery programme: forestry companies engage in replanting when they deforest plots, which has led to "forest management in Lithuania [...] rather intensive and sustainable during the last decades" (Vaitkus, Vaitkuvienè 2005).

In Latvia, the development of various environmental protection laws was a long process (Brunina et al. 2011). It was carried out in the context of political, social, and economic changes that allowed "illegal use of natural resources and quite often also degrading of natural territories" (Nitavska, Zigmunde 2013). Accession to the European Union (2004) and the obligation to follow up on the inherent directives allowed the promulgation of new planning legislation, although there are still deficiencies: for example, no law on coastal erosion is dedicated to coastal activities (Brunina et al. 2011).

There is no independent or specific legislation for the coastal zones in Russia: the country is a rare exception in Europe (Afanasyeva 2014). This lack of regulation is at the root of many conflicts of interest between coastal activities and makes it difficult to put in place measures to reconcile the rational use of coastal resources with nature protection (Bass 2015).

The "lack of definition of the main pressures on biodiversity" (OECD 2019) could explain "the uncontrolled construction of buildings on the coast in connection with the development of tourist activities" (Kraus, Meyer 1998).

The development of coastal zone legislation is strongly influenced by the development of international strategies and programmes such as (Gulbinskas et al. 2009):
- The Helsinki Convention (1995), which provides for the objectives of combating pollution, protecting habitats and biological diversity, and the rational use of marine resources (HELCOM);

- The Recommendation of the European Parliament and the European Council concerning the implementation of the principles of Integrated Coastal Zone Management (2002), which promotes the conservation and the development of economic activities as well as the integration of different planning tools and documents, at multiple scalar scales; and

- The Birds (1979) and Habitats (1982) Directives, the implementation of which involves the establishment of the Natura 2000 network imposing restrictions on specific areas for the protection of fauna and flora (Bagdanavičiūte 2008; Moritz 2008).

\section{What are the limits of coastal protection and management strategies?}

The costs of erosion control operations are high, whether they are "soft" or "hard" solutions. In Lithuania, expenditure to preserve coastal dunes amounts to almost $15,000 €$ per kilometre of coastline and justifies limited action on critical sections (Spiriajevas 2014). In Kaliningrad Oblast, funding is proving to be increasingly insufficient to the point that "the pace of restoration work lags far behind the rate of coastal destruction" (Eaglet 1999): an increasing number of human settlements are now vulnerable to erosion, especially during storm events (Burnashov 2011).

The effectiveness of coastal defence structures is questioned: "the durability of operation of gabions in stormy conditions raises great doubts" (Bass 2015). In Kaliningrad Oblast, they have been able to restore the geomorphological "good state" of the coastline, but these solutions can only protect the coastline over a limited length; more marked erosion is often observed downstream of these structures (Pranzini, Williams 2013). They are also responsible for a decrease in sedimentary inputs in the north of the Sambia Peninsula and along the Curonian Spit (Karmanov et al. 2018). In Latvia, it is estimated that "around 40 per cent of the existing coastal protection structures can ensure only short-term or partial protection of the endangered objects since they are inappropriate for local situations and are in critical conditions". These problems add to the fact that only a very small part of the coastline is protected (Pranzini, Williams 2013).

Environmental protection laws are criticized for being too restrictive for the development of economic activities in Lithuania (Spiriajevas 2014). In 
Latvia, this "overprotection" is even at the origin of the "number of illegal coastal protection solutions set up along the Latvian coastline" which "may end up in coastal erosion on the even larger extent, especially in cases of a hard solution" (Brunina et al. 2011). Planning policies based on "integrated" management come up against public and private interests, which are particularly sensitive in unprotected coastal areas (Spiriajevas 2014). In the Curonian Spit, in the Lithuanian National Park, the main tensions focus on the desire of the municipalities to develop more tourism and on the wish of the local inhabitants to be more involved in the governance of the park. The missions of the Lithuanian National Park are difficult to implement because they are also part of transboundary cooperation with the Russian Curonian Spit National Park. It does not have the same approach: planning and protection appear to be secondary in the Russian part, as the park has no control over municipalities (and thus no restrictions on construction, for example). The focus is more on the development of eco-tourism. The Russians want to collaborate in a limited way such as the implementation of a unified tourist information system, for example, while the Lithuanians expect broader cooperation with mutual learning (Moritz 2008).

These policies of protection and management strategies require significant financial and human resources for their implementation, which are insufficient in Lithuania (Žilinskas 2008). The same is true in Latvia, where former military sites and collective farms were denationalized or privatized in the early 1990s. The lack of coastal management strategies leads to unclear situations and the emergence of divergent interests, creating multiple cases of abuse that lead to "uncontrolled territory development or landscape degrading and inaccessibility of landscape" (Nitavska, Zigmunde 2013). These territories which have remained without legal owners have been subject to damage to natural and cultural heritage objects, despite the former Soviet regulations guaranteeing their protection - a ban on building in dune areas, for example (Nitavska, Zigmunde 2013; Brunina et al. 2011). Protected areas lack management plans and are insufficiently funded to be fully effective (OECD 2019).

\section{CONCLUSIONS}

Since the end of the 1980s, the countries of the south-eastern Baltic Sea have been experiencing a particularly intense and rapid anthropisation of the coastal zone, due to political, social, and economic changes associated with the end of the Soviet Union. These pressures are exerting themselves on a highly sensitive environment, which until then had remained relatively untouched by any major development with the militarization of the coasts.

The changes are manifested firstly by the strengthening of human stakes in the coastal regions, due to the increasing concentration of specific economic activities with industry and tourism; secondly, by the increase in urbanised areas, with phenomena of periurbanisation and the decline of the agricultural sector.

These changes are also reflected in a clear degradation of the coastline and disruption of the natural dynamics which influence its evolution. As a result, many environmental problems have been identified, such as water and soil pollution, the weakening of coastal ecosystems, and the increase in coastal erosion, the evolution of which is increasingly conditioned by human action.

Consequently, the public authorities have developed policies for the management and protection of the coastal zone, linked to the global context of environmental awareness. However, these policies differ between the three countries in the study in terms of the strategies adopted and the technical, legal, financial, human, and other means put in place to achieve the objective of "sustainability", making it possible to reconcile environmental protection and economic development in coastal regions.

Lithuania seems to be the country that comes closest to this objective, although Latvia is gradually catching up in terms of environmental policy, thanks, among other things, to the application of directives and conventions at the European and international level (UNESCO, RAMSAR). Nevertheless, in the context of climate change and the ever-increasing anthropisation of the coastal regions, it seems necessary to further develop coastal area management on the scale of the Baltic Sea in territories that have remained fundamentally interdependent with each other.

\section{ACKNOWLEDGMENTS}

We would like to thank the reviewers for their key comments and suggestions. This research is supported by the CNES AICMEE TOSCA programme (Apport de l'Imagerie satellitaire Multi-Capteurs pour répondre aux Enjeux Environnementaux et sociétux des socio-systèmes urbains).

\section{REFERENCES}

Afanasyeva, E.P. 2014.Characteristics of tourism development in the coastal areas of the Kaliningrad region. Pskov Journal of Regional Studies 18. [In Russian].

Andersen, J., Carstensen, J., Conley, D., Dromph, K., Fleming-Lehtinen, V., Gustafsson, B., Josefson, A., Norkko, A., Villnäs, A., Murray, C. 2017. Long-term 
temporal and spatial trends in eutrophication status of the Baltic Sea. Biological Reviews 92, 135-149.

Armaitienè, A., Boldyrev, V.L., Povilanskas, R., Taminskas, J. 2007. Integrated shoreline management and tourism development on the cross-border World Heritage Site: A case study from the Curonian spit (Lithuania/Russia). The Journal of Coastal Conservation 11 (1), 13-22.

Bagdanavičiūtė, I., Blažauskas, N., Brzezinska, A., Chubarenko, B., Cieslak, A., Dailidiene, I., Domnin, D., Gajewski, J., Gajewski, L., Gulbinskas, S., Kałas, M., Matczak, M., Mikelenaite, J., Milerienè, R., Rybka, K., Staśkiewicz, A., Stawicka, I., Szefler, K., Visakavičius, E. 2008. State of the coast of the South East Baltic: an indicators-based approach to evaluating sustainable development in the coastal zone of the South East Baltic Sea.

Bagdanavičiūtè, I., Kelpšaitè, L., Daunys, D. 2012. Assessment of shoreline changes along the Lithuanian Baltic Sea coast during the period 1947-2010. Baltica 25 (2), $171-184$.

Bass, O. 2015. Modern conception of coastal protection and problems of hydraulic engineering in Kaliningrad region. Vestnik IKBFU (1). [In Russian].

Bird, E. 2010. Encyclopedia of the world's coastal landforms. Springer Science \& Business Media.

Bitinas, A., Žaromskis, R., Gulbinskas, S., Damusytė, A., Žilinskas, G., Jarmalavičius, D. 2005. The results of integrated investigations of the Lithuanian coast of the Baltic Sea: geology, geomorphology, dynamics and human impact. Geological Quaterly 49 (4), 355-362.

Brunina, L., Rivza, P., Konstantinova, E. 2011. Coastal Spatial Planning Problems in Latvia. Journal of Coastal Research, Special Issue 64: Proceedings of the $11^{\text {th }}$ International coastal symposium ICS2011, 1224-1227.

Burnashov, E. 2011. Current coastal dynamics in the Kaliningrad region, based on annual monitoring surveys. Issues of modern science and practice. Vernadsky University. VI Vernadsky (2), 10-17. [In Russian].

Center for International Earth Science Information Network (CIESIN), Columbia University. 2012. "National Aggregates of Geospatial Data Collection: Population, Landscape, And Climate Estimates, Version III (PLACE III)". Retrieved from https://sedac.ciesin. columbia.edu/data/set/nagdc-population-landscapeclimate-estimates-v3

Danielson, J.J., Dean, B.G. 2010. Global multi-resolution terrain elevation data 2010 (GMTED2010). US Department of the Interior, US Geological Survey.

Eaglet, V. 1999. Environmental problems of the Baltic Sea and the Kaliningrad region. [In Russian].

European Marine Observation and Data Network (EMODnet), Geological Survey of the Netherlands (TNO), Deltares. 2019. "Coastal Migration - from satellite data”. Retrieved from https://www.emodnet-geology. eu/data-products/coastal-behavior/

European Space Agency Climate Change Initiative, Land Cover project. 2017. "300 m Annual Global Land
Cover Time Series from 1992 to 2015 ". Retrieved from https://www.esa-landcover-cci.org/?q=node/175

Fedorov, G.M., Kuznetsova, T., Razumovkii, V.M. 2017. How the Proximity of the Sea Affects Development of Economy and the Settlement in Kaliningrad Oblast. Regional Research of Russia 7 (4), 352-362.

Gadal, S. 2010. Urban dynamics in Kaliningrad and Klaipeda coastal regions by remote sensing and GIS. Bridges/Tiltai 50 (1), 101-110.

Gadal, S. 2011. Habilitation à Diriger des Recherches Volume 1: Métropolisations, territoires émergents et systèmes géographiques d'information et de modélisation territoriale. Université Paris Diderot Paris 7.

GEBCO Compilation Group. 2019. GEBCO 2019 Grid. Retrieved from https://www.gebco.net/data and products/gridded_bathymetry_data/gebco_ $\overline{2} 019 /$ gebco_2019_info.html

Gulbinskas, S., Suzdalev, S., Mileriene, R. 2009. Coastal management measures in Lithuanian Baltic coast (South Eastern Baltic). Coastal Engineering 2008 (In 5 Volumes), 4042-4052.

HELCOM BRISK Project. 2013. Retrieved from: https:// helcom.fi/helcom-at-work/projects/brisk/

HELCOM (a). 2018. State of the Baltic Sea - Second HELCOM holistic assessment 2011-2016. Baltic Sea Environment Proceedings, 155.

HELCOM (b). 2018. HELCOM Assessment on maritime activities in the Baltic Sea 2018. Baltic Sea Environment Proceedings, 152.

Jarmalavičius, D., Žilinskas, G., Kulvičienè, G. 2001. Peculiarities of long-term water level fluctuations on the Lithuanian Coast. Acta Zoologica Lituanica 11 (2), 132-140.

Jarmalavičius, D., Žilinskas, G., Pupienis, D. 2012. Impact of Klaipèda port jetties reconstruction on adjacent sea coast dynamics. Journal of Environmental Engineering and Landscape Management 20 (3), 240-247.

Karmanov, K., Burnashov, E., Chubarenko, B. 2018. Contemporary Dynamics of the Sea Shore of Kaliningrad Oblast. Archives of Hydro-Engineering and Environmental Mechanics 65 (2) 143-159.

Kraus, H., Meyer, T. 1998. Environmental Policy in Latvia. European Parliament. [In French].

Łabuz, T. 2015. Environmental Impacts - Coastal Erosion and Coastline Changes. In: The BACC II Author Team. Second Assessment of Climate Change for the Baltic Sea Basin, Region Climate Studies, Springer, 381-396.

Lavrova, O., Nazirova, K., Krayushkin, E., Strochkov, A. 2019. Concurrent Field Experiments and Satellite Surveys for Assessing Environmental Risk in the Coastal Zone of Southeast Baltic. Ecologica Montenegrina 25, 44-54.

Mishurinsky, D., Bredikhin, A. 2015. Recreational and geomorphological information support for tourism on the coast of the Kaliningrad region. In: Geomorphological resources and geomorphological safety: from theory to practice All-Russian conference, 246-247. [In Russian]. 
Mochalov, E. 1999. The environmental reality and the place of the Kaliningrad region in it. In: Eaglet, V. (ed.) Environmental problems of the Baltic Sea and the Kaliningrad region. [In Russian].

Moritz, A. 2008. Governance of the National Parks on the Curonian Spit. Applied Management, Conflicts and Stakeholder co-operation [Master thesis]. University of Joensuu.

Nitavska, N., Zigmunde, D. 2013. The impact of legislative rules and economic development on the coastal landscape in Latvia. Civil engineering'13, 259.

OECD. 2019. OECD Environmental Performance Reviews: Latvia 2019 (short version). OECD Environmental Performance Reviews. OECD Publishing. [In French].

Olenina, I., Olenin, S. 2002. Environmental Problems of the South-Eastern Baltic Coast and the Curonian Lagoon. In: Schernewski, G., Schiewer, U. (eds) Baltic Coast Ecosystems. Central and Eastern European Development Studies, 149-156. Springer, Berlin.

Povilanskas, R., Urbis, A. 2004. National IZCM strategy and initiatives in Lithuania. Coastal Reports 2, 9-15.

Pranzini, E., Williams, A. 2013. Coastal Erosion and Protection in Europe. Routledge.

Sciavina, M., Freire, S., MacManus, K. 2019. GHS population grid multitemporal (1975-1990-2000-2015),
R2019A. European Commission, Joint Research Centre $(J R C)$. Retrieved from: https://data.jrc.ec.europa. eu/dataset/0c6b9751-a71f-4062-830b-43c9f432370f

Spiriajevas, E. 2014. Hindrances and suggestions for sustainable development of Lithuanian Coastal Strip (Zone). Regional Formation and Development Studies $6(1), 125-136$.

Vaitkus, G., Vaitkuvienè, D. 2005. Land cover changes in the Lithuanian coastal zone during 1975-2000. Acta Zoologica Lituanica 15 (2), 183-187.

Veteikis, D., Šabanovas, S., Jankauskaitè, M. 2011. Landscape structure changes on the coastal plain of Lithuania during 1998-2009. Baltica 24 (2), 107-116.

Vinogradova, S. 2017. Analysis of the dynamics of anthropogenic load of the coastal zone of the Kaliningrad region (1938-2016). In: The unity and identity of science: problems and solutions Conference 4, 205-209. [In Russian].

Vogt, J., Soille, P., De Jager, A., Rimaviciute, E., Mehl, W., Foisneau, S., Bodis, K., Dusart, J., Paracchini, M.L., Haastrup, P., Bamps, C. 2007. A pan-European river and catchment database. Report EUR 22920.

Žilinskas, G. 2008. Distinguishing priority sectors for the Lithuanian Baltic Sea coastal management. Baltica 21 (1-2), 85-94. 